\title{
Conservation and reconstruction of art paintings of the late nineteenth century in the lobby of the academic building of L'viv Polytechnic National University
}

\author{
Mykola Bevz \\ Department of Conservation of Built Heritage, Lublin University of Technology \\ Department of Architecture and Conservation, Lviv Polytechnic National University

\section{Serhiy Hetmanchuk} \\ Department of Architecture and Conservation, Lviv Polytechnic National University
}

\begin{abstract}
The research of artistic decoration and practical works of restoration of wall paintings of the main lobby of former building of the Galician Highest Regional Court presented in the article. The building used today as academic korp for the needs of L'viv Polytechnic National University. The first part of the restoration work was carried out in this building during 2012-2014 years.
\end{abstract}

Key words: the lobby of academic building, former building of the Galician Highest Regional Court, art paintings of the 19th cent., conservation and reconstruction, Lviv, $19^{\text {th }}$ cent.

\section{Introduction}

The works on conservation and reconstruction of art paintings in the main lobby of the $19^{\text {th }}$ academic building (located in the city center on 1-3 Kniazia Romana Street) were executed by the order of Rector of L'viv Polytechnic National University - professor Yuriy Bobalo. The permission for research work was received in autumn 2011. Nowadays the building is used for the needs of L'viv Polytechnic National University, is the architectural monument of local importance and one of the most representative public buildings in L'viv from the end of the nineteenth century, built by the Austrian administration of Galicia. In 2008, part of the building's premises was transferred to the Department of Architecture and Conservation for educational use. The department specialists have found remains of artistic wall and ceiling paintings (covered over during Soviet times) in all parts of the building interiors (entrance lobbies, assembly hall, corridors and cabinets). The works on research and restoration of the main lobby paintings are only the first part of the restoration work to be carried out in this building.

\section{Outline on the history of the building}

The $19^{\text {th }}$ century academic building of L'viv Polytechnic National University, located on 1-3 Kniazia Romana Street, is the former administrative building of the Galician Highest Regional Court, also called the 'Palace of Justice' (Fig. 1). The building was buit in 1891-1895 in the Neo-Renaissance style by the design of L'viv architect Franz Skowron and architect from Krakow Jan Zawiejski [Architektura L'vova, 2008]. It is believed that the Krakow architect chaired the work on the facade finishing [Bevz, 2013]. The art decoration of interiors was probably designed by sculptor Leonardo Marconi and painter Tadeusz Popel [Eder, 2014]. 
Molded decoration of facades is made in special technology using 'Roman' cement [Bevz, 2013], the material that was used in decorating of the most significant buildings of L'viv in the second half of the nineteenth century - the Galician Savings Bank, the Parliament of Galicia, the Galician Vicegerency, the Opera House, etc. [Bevz, 2014]. The building of the Galician Highest Regional Court was built on the site of the disassembled buildings of the monastery complex of the Carmelites (branch of the so-called Calced Carmelite order, Fig. 2).

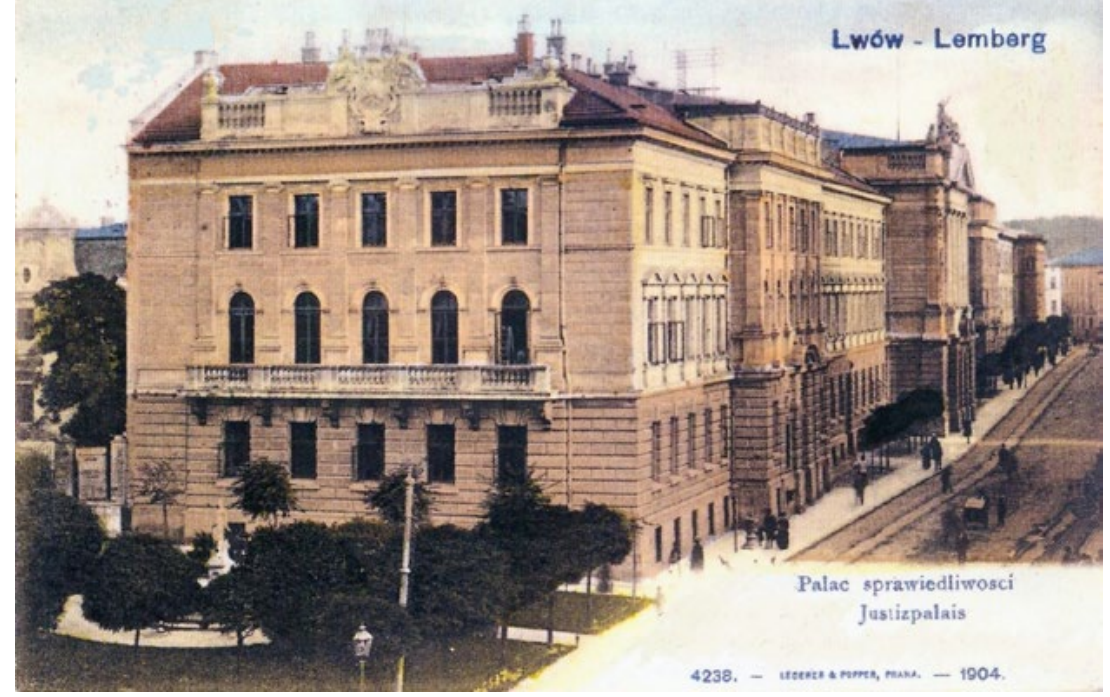

Fig. 1. Photo of the main facades of the Galician Highest Court in 1904 [Irina Kotłobułatowa, 2002].

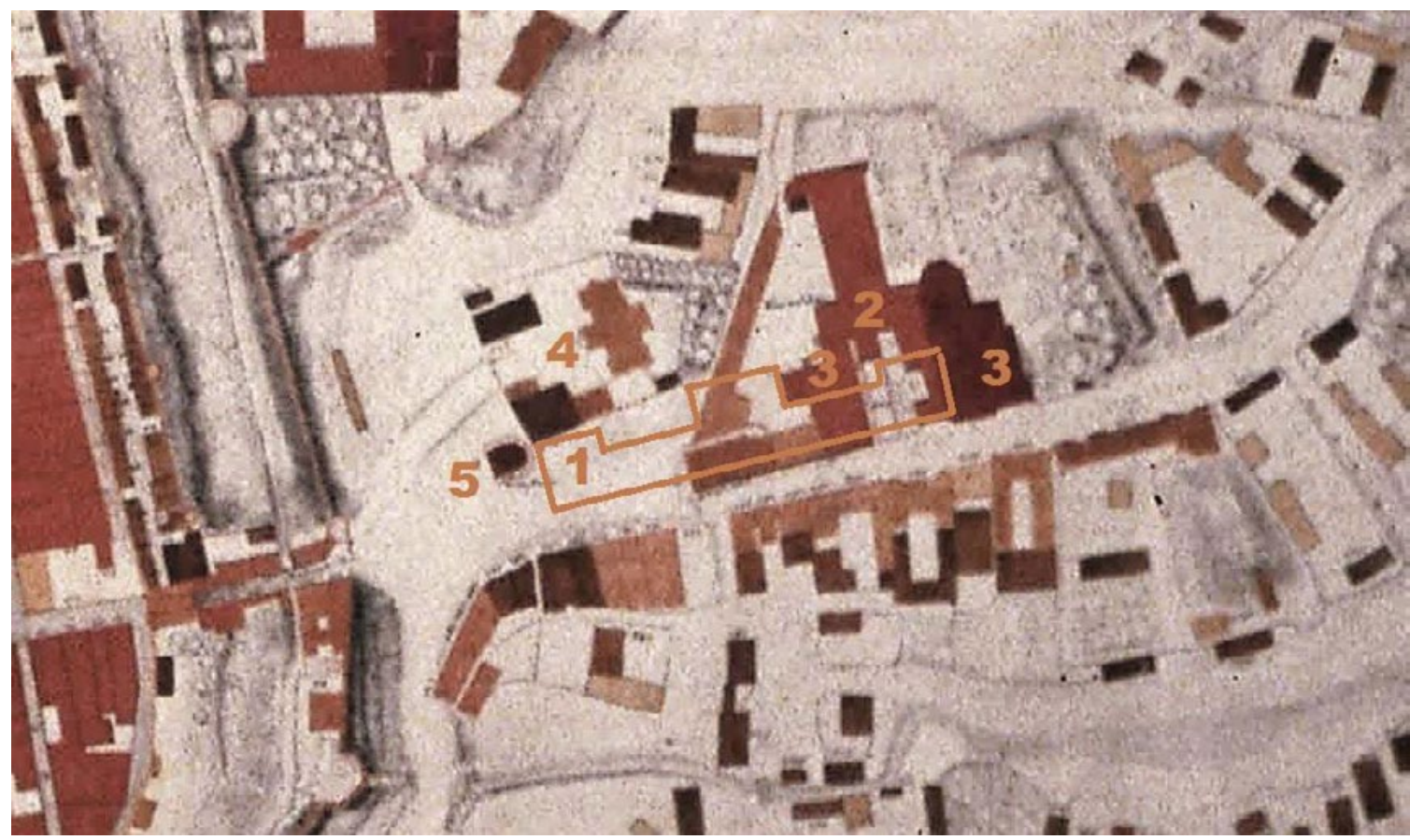

Fig. 2. The fragment of the map of L'viv by Daniel Guber (1777, Kreagsarchiv, Wien), indicating the location of the institution of the Galician Highest Court on the site of the dismantled buildings of the monastery of Calced Carmelite order: 1 -indicative contour of the building of the Regional Court; 2 - preserved building of the monastery of the XVII century; 3 - lost buildings of the temple of St. Leonard and other monastic objects of the Order; 4 - Palace of Besiadecki-Komorowski family; 5 - building of the church of the Holy Cross on the Halytska square (disassembled later). Photo of the map and marking - M. Bevz. 


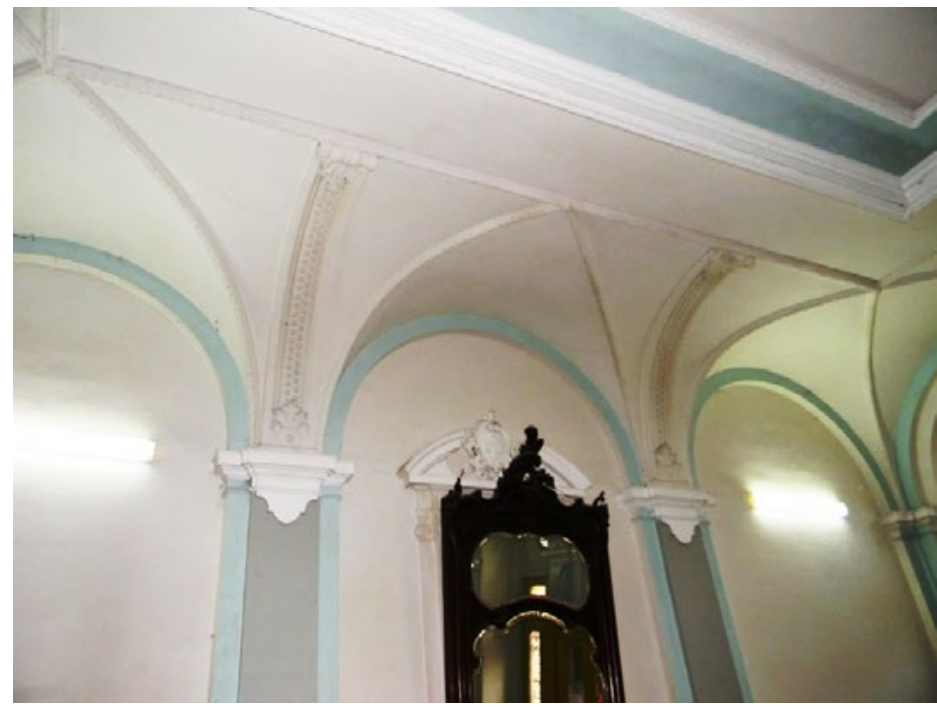

Fig. 3. Photo of the western wall of the lobby before the conservation works, 2012 (photo by M. Bevz).

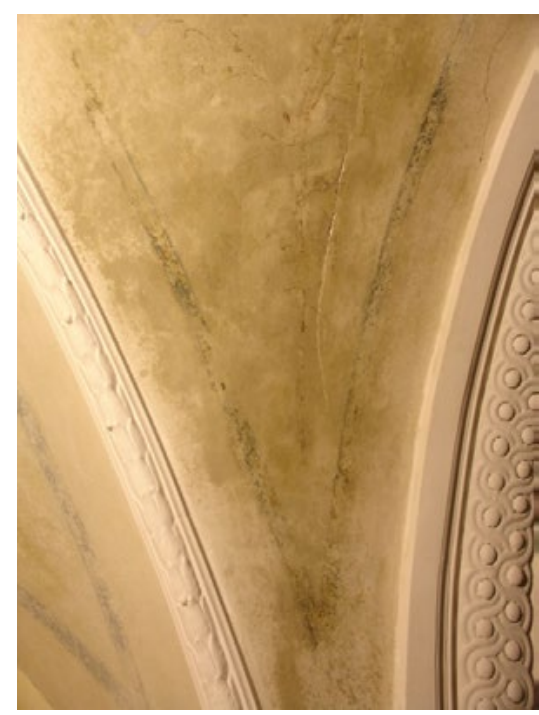

Fig. 4. Saved under a later covering a fragment of art paintings of the XIX century (photo by M. Bevz).

The interiors of the building of the Galician Regional Court had a rich artistic style - molded architectural decoration (pilasters with column caps, framing of windows and doors in all corridors; a balustrade on the main staircases, sculptural figures in the most important places, painted vault and ceilings). The richest paintings on the vault and on the walls were in the assembly hall on the second floor (the paintings are preserved), vaults and the walls of the lobby of the service entrance on the left wing of the building (the paintings are preserved but they needed conservation). There were also paintings on the vault and the walls of the main lobby, the foyer in front of the assembly hallon the second floor but these paintings were demolished during the Soviet period [Archive of the department..., 2012].

In the former cabinet of the head of the Highest Court, which is on the third floor, the authentic decoration of the interior by the artistic allegorical plot of the paintings on the canvas, which covers the ceiling, remains till now. The author of the canvas was found - it's Tadeusz Popel. Therefore we can make a preliminary conclusion that was the artist who could be the author of artistic decoration of the rest of the building's interior.

The decision to start work on the study of the building's lobby was made at the meeting of the Rector of L'viv Polytechnic in September 2012, when the results of the first findings of the traces of floral painted decorations on the ceiling were unveiled (fig. 1,2). The program of probing research findings revealed in the paintings of the walls and the ceiling of the lobby was approved at the meeting of the department in October 2012. The "conservation task" and the concept of reconstruction of paintings in the main lobby were approved in June 2013 after completion of the probing research program [Archive of the department..., 2012].

\section{Results of probing studies and revealation, laboratory tests}

The ceiling of the lobby is shaped as a nocturnal vault with planking and is combined with bricked-concrete contracture. Plankings (lunettes) are made of bricks and are covered with limestone and sandy plaster. The horizontal central part of the concrete ceiling also has limestone and sandy plaster. The walls are made of brick and are covered with lime and sandy plaster. The ceiling has a scenery of stucked molding modeling. 


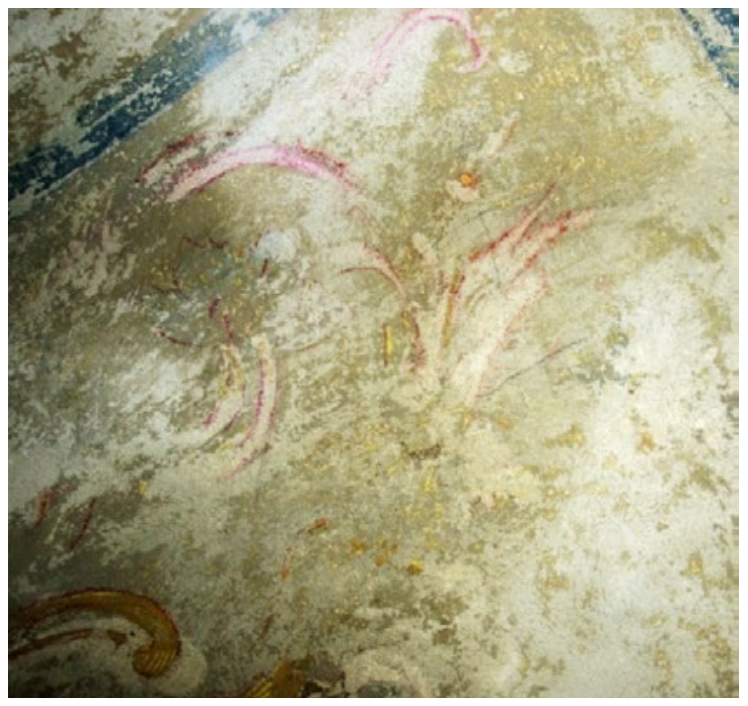

Fig. 5. Decorative element of the ornament. Probing before the conservation, 2013. Photo by S. Hetmanchuk.

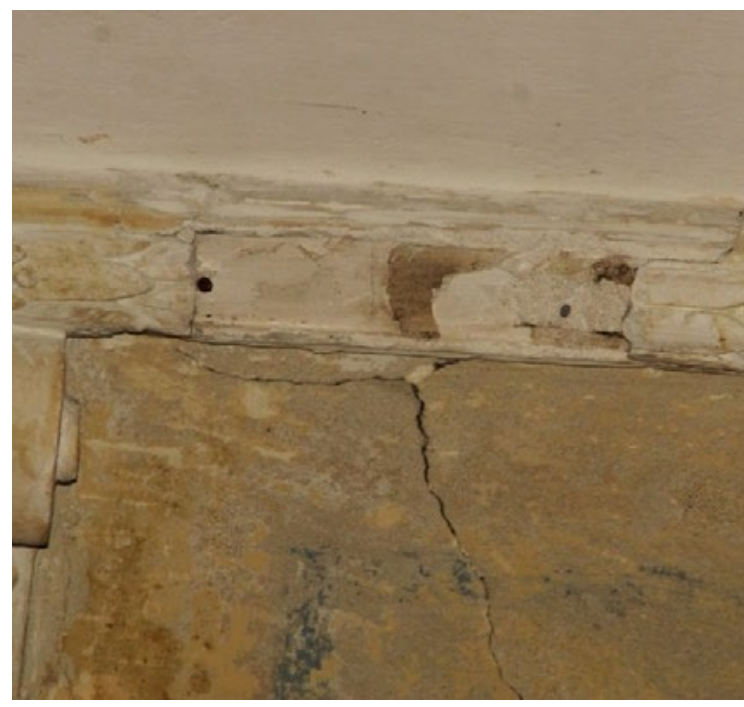

Fig. 7. Cracks on the surface of the vaults and loss of the molded ceiling decoration. Probe before the conservation, 2012. Photo by S. Hetmanchuk.

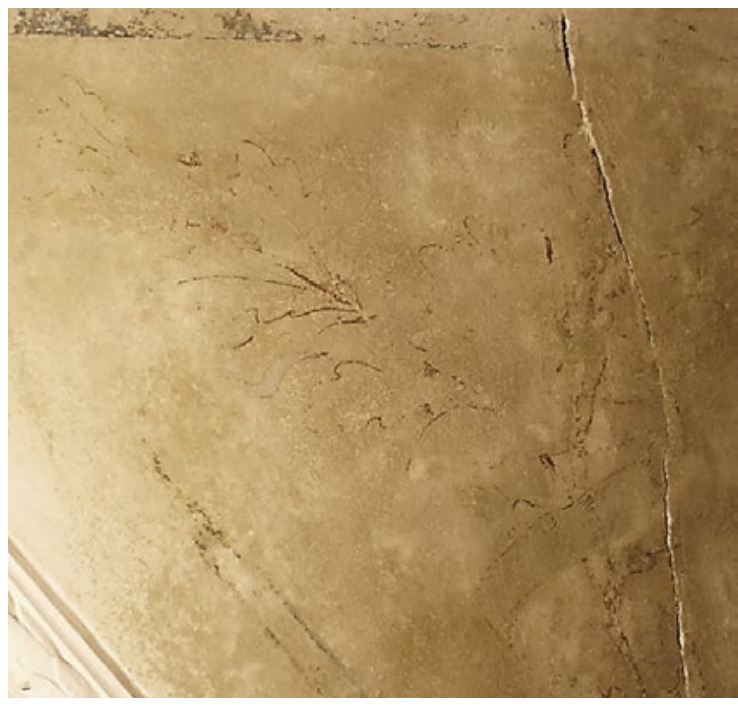

Fig. 6. The fragment of a decorative branch with oak leaves. Probe before conservation, 2012. Photo by S. Hetmanchuk.

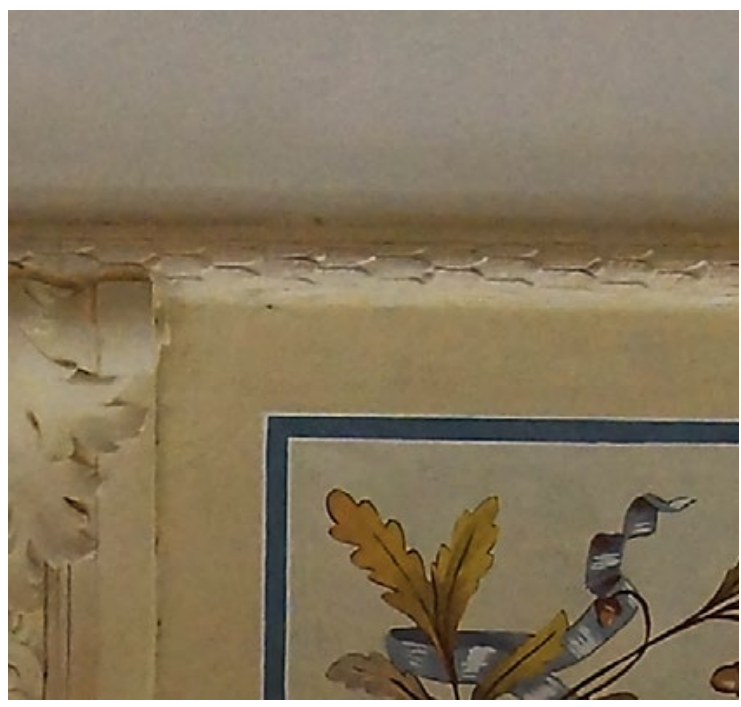

Fig. 8. The same fragment of the vault' surface of the molded decorations after the conservation, 2015. Photo by S. Hetmanchuk.

During the probing the remains of art paintings were found on the vaults of the lobby. The state of the remnants was different. In most 'fields' of the vaults the remnants of the paintings were barely readable. Only in the corners of the ceiling, the state of the paintings was a bit better. It was in these fields that in several surfaces, mechanically cleared with the help of brushes and scalpel from the later cretaceous-glutinous layer. Due to this method, the elements of the ornament were discovered, which made it possible to more accurately characterize the type of paints and the style of painting and reconstruct the original drawing pattern on tracing paper. It was discovered that the fields of the vaults were covered with repeating painted floral compositions. Unfortunately, the state of preservation of paintings in most fields was very bad (see photos 5 and 6 ). In addition, the plaster surface of the ceiling had numerous microcracks. On the ceiling there was also molded gypsum decoration in the form of molds. The molds imitated bay leaves' weaving. There were lost parts in several places and some of the leaves were cracked (Fig. 7). 
As a result of the research, it was found that the background under the ornaments was performed on the cretaceous-glutinous basis with the addition of mineral pigments, the paintings themselves were made with waterproof casein paint, as evidenced by the ochroid trace under its surface.

The discovered fragments of the ornaments had features of Neo-Renaissance paintings, as evidenced by plant elements in the form of acanthous leaves, volute, silhouette of cartouch in a large triangle (Fig. 5), and oak branch with a ribbon in small triangles (Fig. 6). The remains of paintings were transferred to tracing paper and used in further work on reconstruction (Fig. 8, 9, 10).

After previous researches, the surface of the ceilings was prepared for further works on the reconstruction of artistic paintings, during which, using warm water and brushes, the surface was cleaned of dirt, paint residues and cretaceous-glutinous solution. Also, after the completion of the cleansing, mechanical damage and cracks in the surface of the vaults and adjacent moldings (Fig. 7, 8) were identified, requiring urgent restoration measures. The next stage was embroidery of cracks and seams, injection of gypsum and the addition of lost elements of molded decoration, with subsequent toning.

\section{The project of conservation and reconstruction of art paintings on the ceiling}

On the basis of materials obtained as a result of previous studies, sketches were made and variants of reconstruction of artistic paintings were offered (Fig. 7, 8) of which the ones that best match the style and character of similar ornaments available in other rooms of the same building were chosen the best suitable. Also, the main and secondary colored tones were approved (Fig. 11), sketches of all elements were made (Fig. 9, 10). At this stage, the composition and color scheme of paints, which were to be used for painting the interiors of the main lobby of the $19^{\text {th }}$ building of L'viv Polytechnic were finally explored and approved. Later, drawings, a color proposal for the reconstruction of paintings and ceilings in general were completed (Fig. 10, 13) [Archive of the department..., 2012].

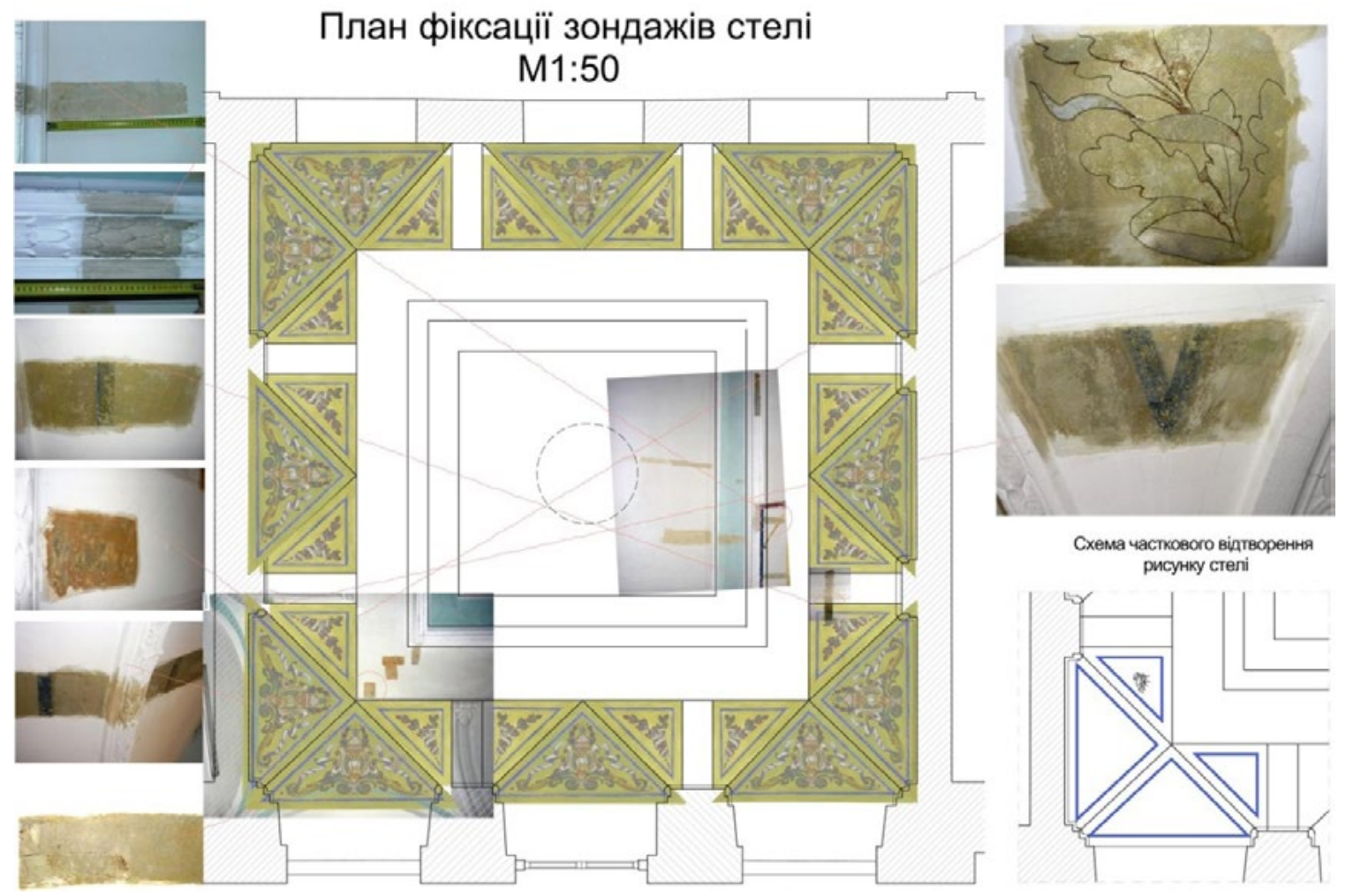

Fig. 9. The project documentation with the results of probing and the concept of reconstruction of paintings, 2013. 

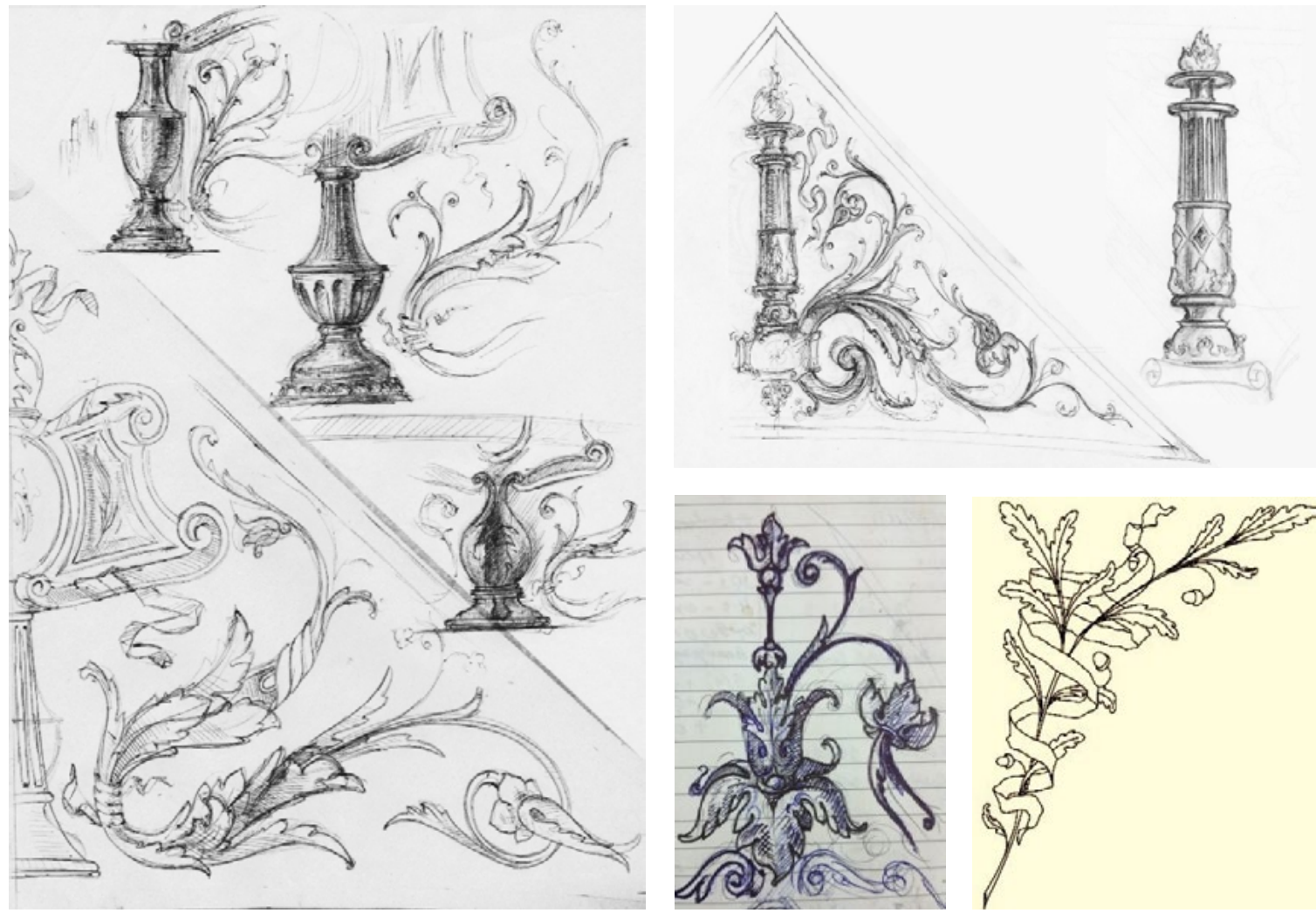

Fig. 10. Sketches of elements of ornamental and plant compositions (S. Hetmanchuk).

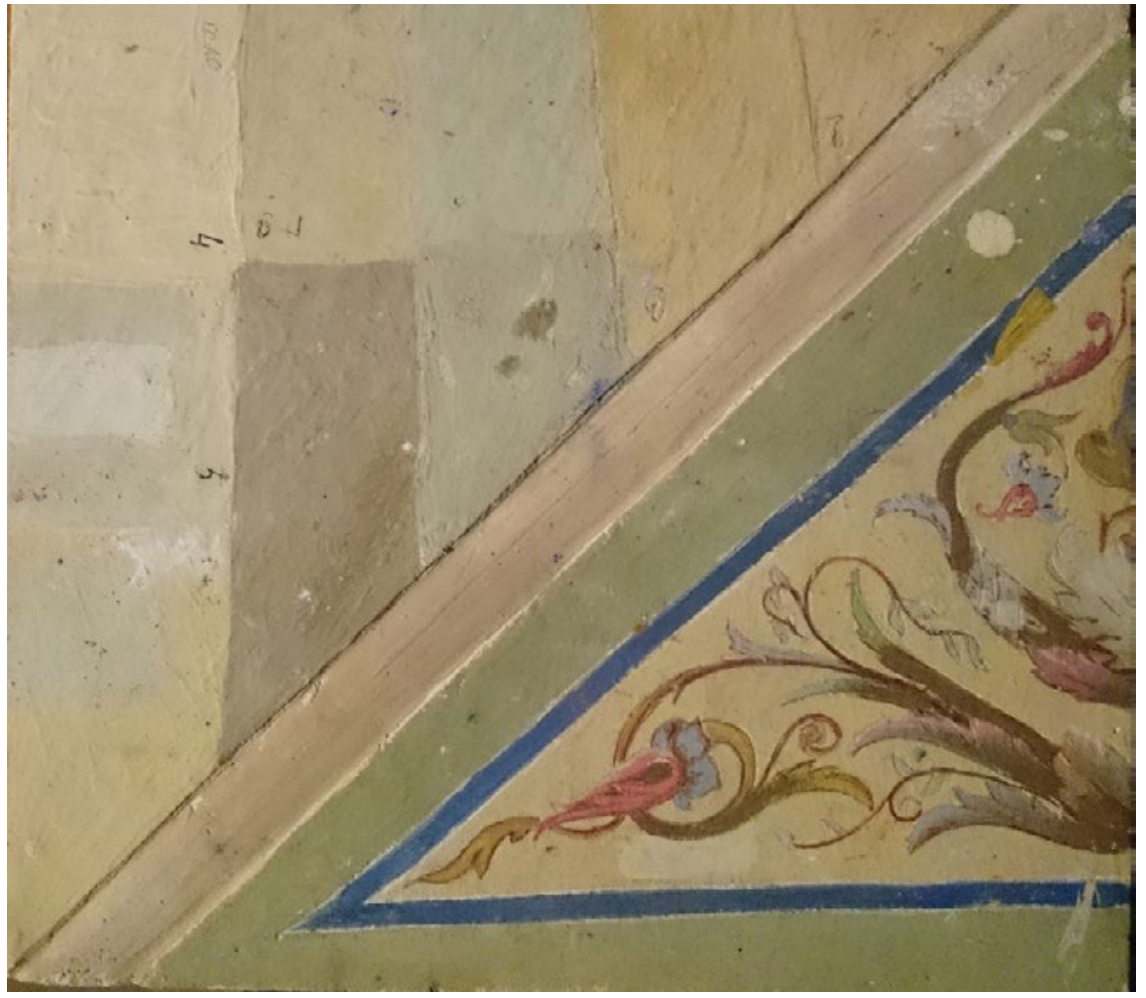

Fig. 11. Tests on colour and the property of casein and cretaceous-glue paints and their compatibility with each other and the basis (author - S. Hetmanchuk). 


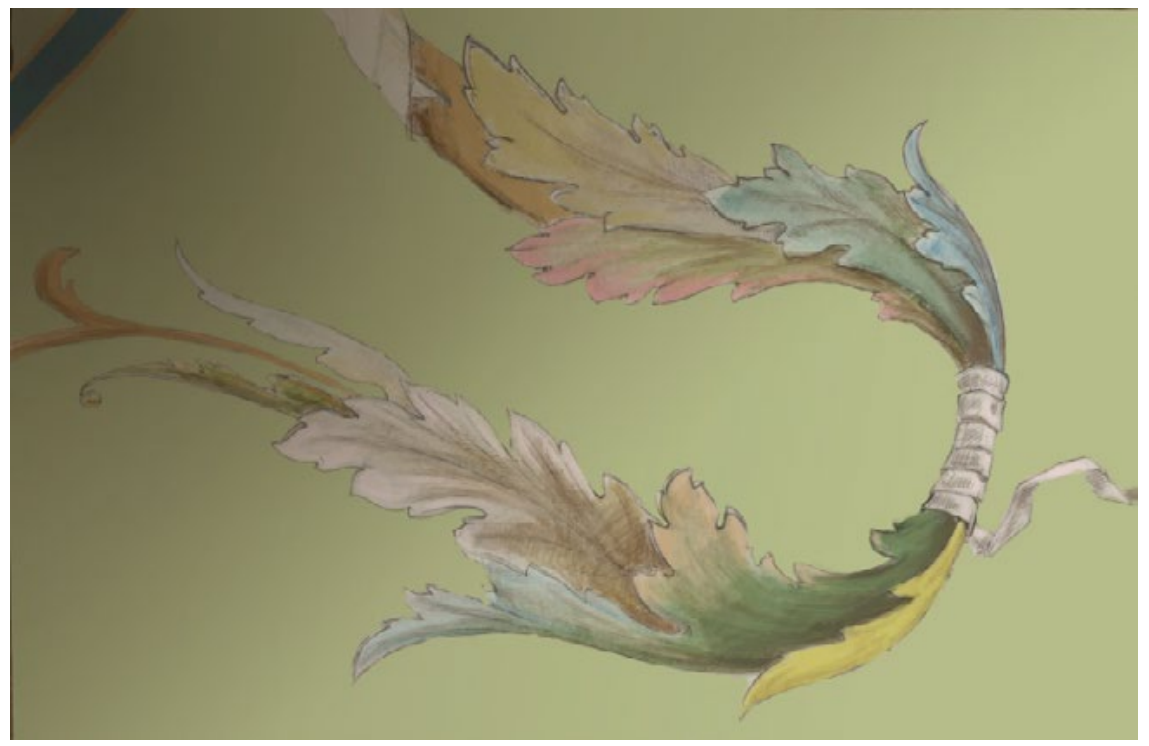

Fig. 12. Coloured sketch in the color of the elements of acanthous leaves (author S. Hetmanchuk).

\section{Practical implementation of conservation and reproduction of art paintings}

After clearing the fields of vaults, first of all, in all the places of the ceiling, the retained fragments of the old painting were fixed.

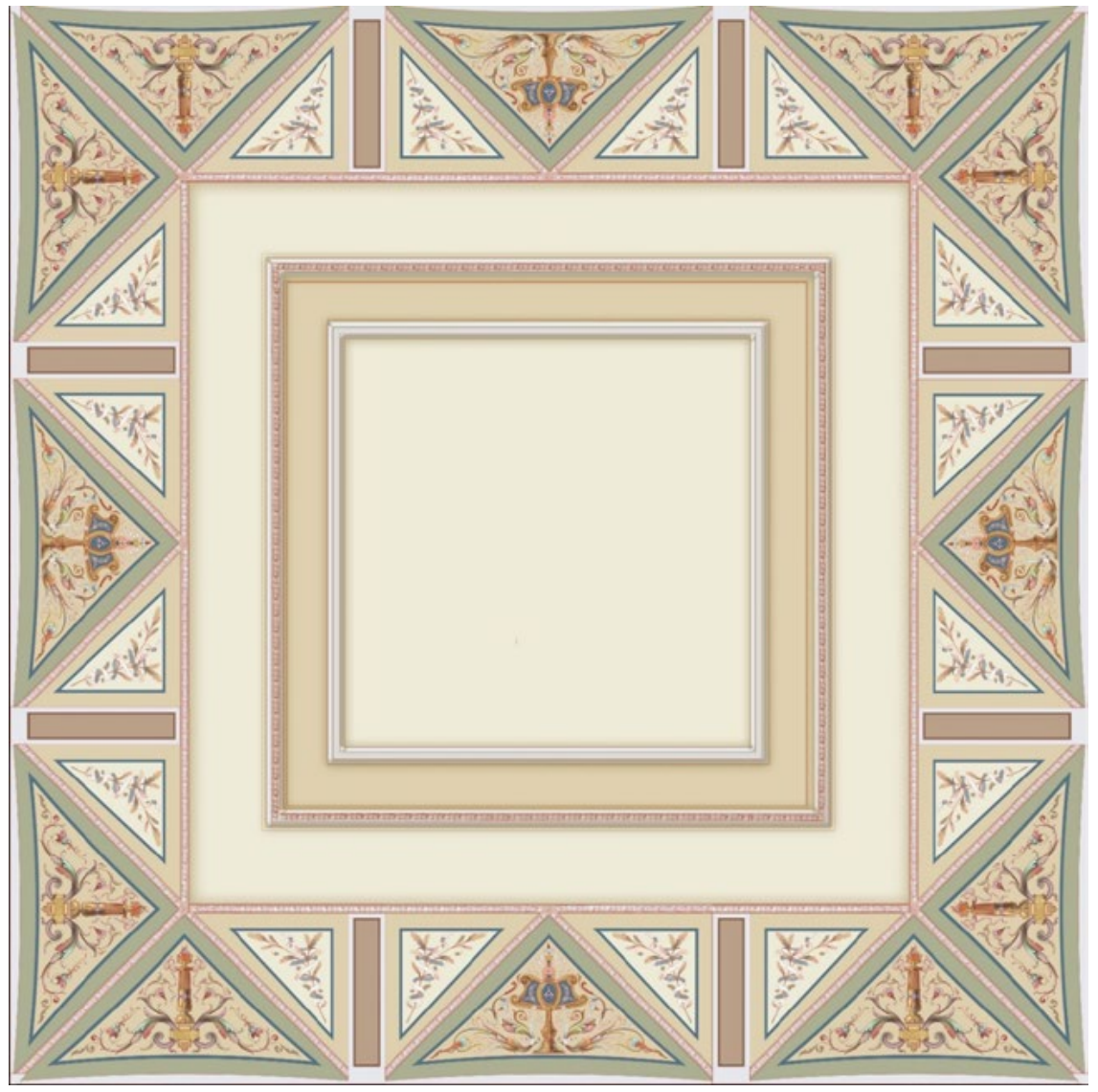

Fig. 13. Plan for the reconstruction of paintings on the ceiling of the main lobby of the $19^{\text {th }}$ academic building with a color proposal (design - M. Bevz, S. Hetmanchuk). 
The authors themselves carried out the preparation of paints for the background and for the reproduction of drawings of ornamental compositions in the fields of the vaults. We used only market-grade factorial mineral pigments. For backgrounds, we used paint on the cretaceous-glutinous basis with the addition of mineral pigments. The composition of the paint included the following ingredients: chalk, gelatin (base, soil), tetraboric acid (antiseptic) and mineral pigments: French ocher, green Veronese and black grape.

Casein paint, which included: casein made from low-fat cheese, hydrated lime, balsam turpentine oil, varnish, boric acid and mineral pigments (mainly cadmium and cobalt) was used for drawings of ornamental-decorative compositions. Also, a sample was performed on the color gamma and the compatibility of colors with each other and the technical and color harmony with the base (Fig. 12). After painting the backgrounds, drawings of the ornament were translated into the surface of the vaults in the technique of pouncing and stencil. Subsequently, art restoration and reproduction works were started. This final stage included: pointing of the contours, drawing of the main tones of the substrate, creating extent in the 'dry brush' technology and the writing of small elements. At each stage of the work, detailed photo fixing and inventory of the processes were carried out.

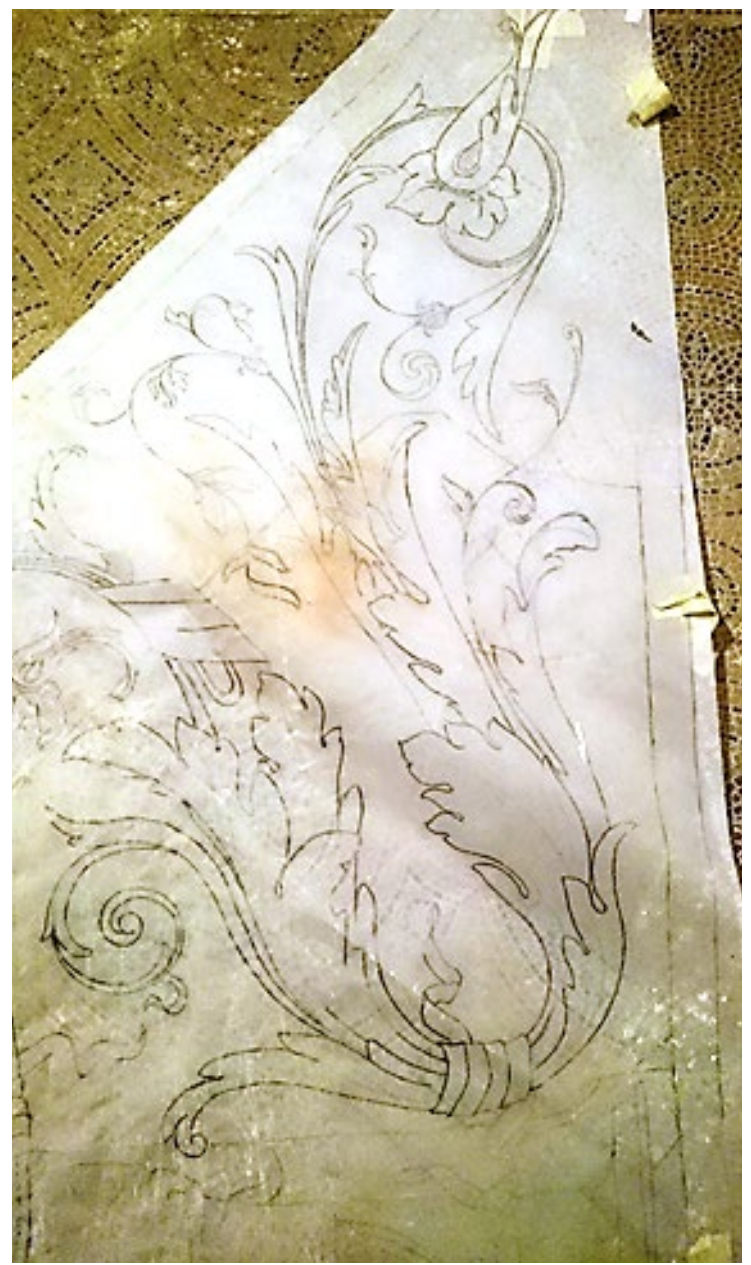

Fig. 14. Tracing with transfer of the patterned ornament on it (scale 1:1).

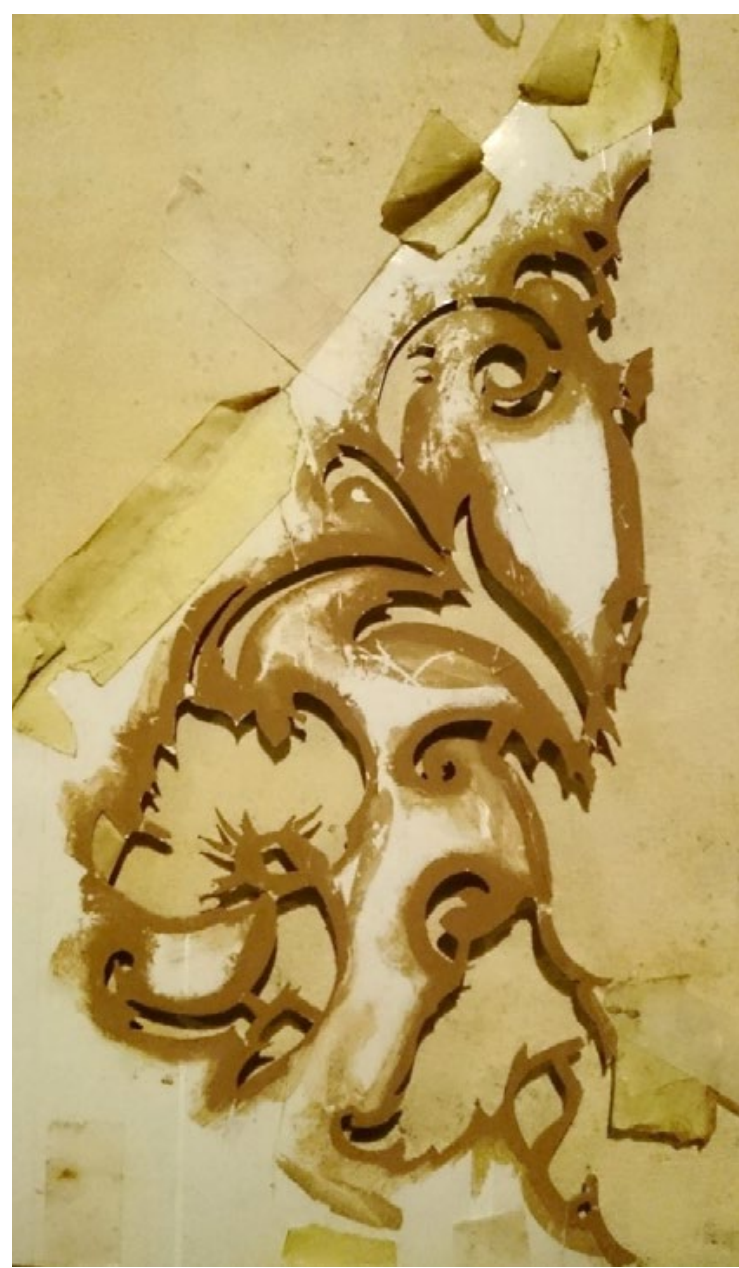

Fig. 15. One of the transferring methods of the drawing to the surface of the vaults, applying paint on a stencil.

The pictures and graphic material of the research, design and execution of the reconstruction and restoration of the paintings of the main lobby of the $19^{\text {th }}$ century academic building are presented on Figures $13-16$. Figure 17 shows the state of the interior of the lobby after the restoration and reconstruction of the paintings on the ceiling. The group of authors that executed this project: prof. M. Bevz - a head, S. Hetmanchuk - practical 
conservation and reconstruction, O. Rybchynskyi, V. Melnyk - participate in research and designing, O. Shych - restoration of stone decoration.
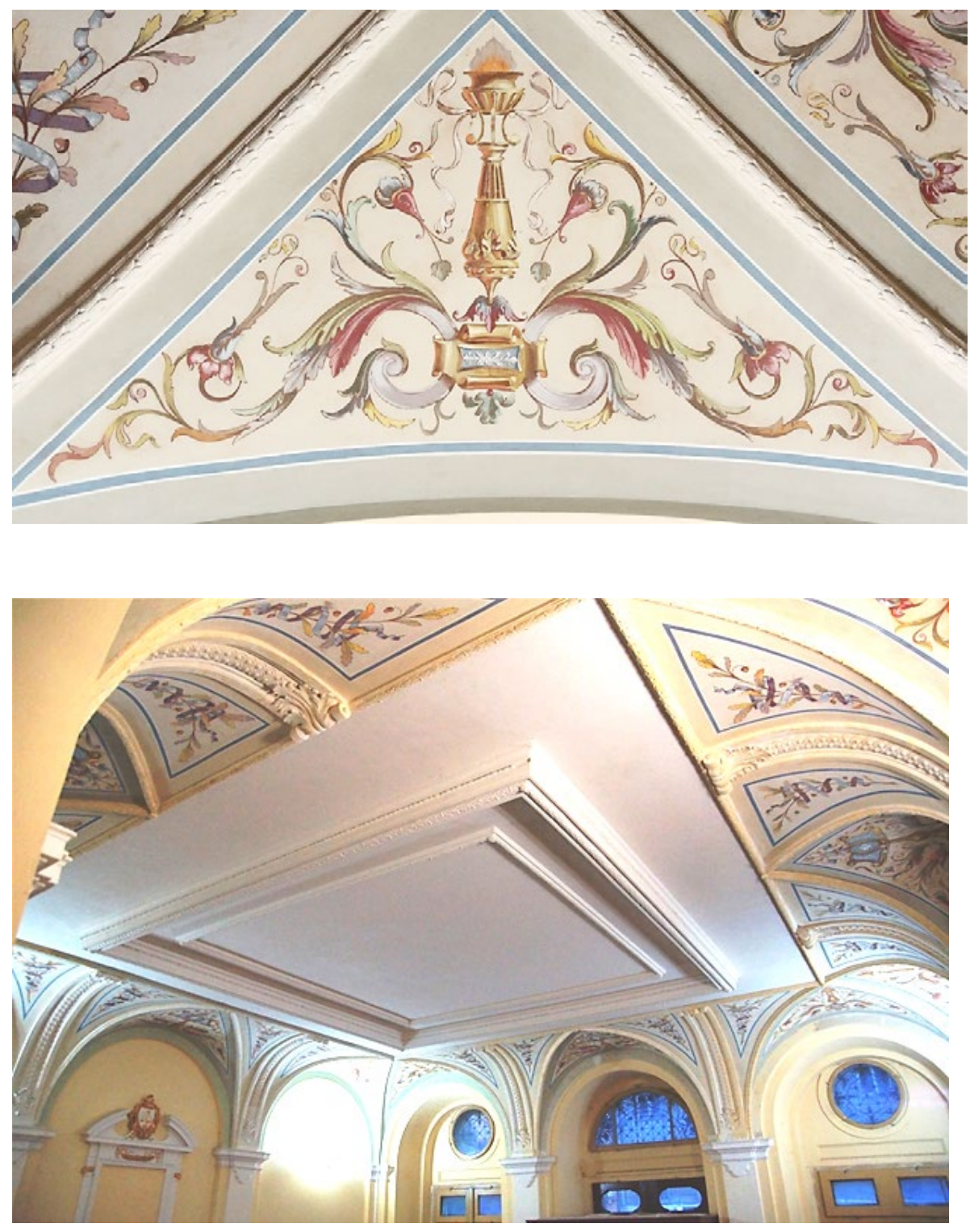

Fig. 16. Conserved and reconstructed triangular field on a vault. Practical work - S. Hetmanchuk.

Fig. 17. The main lobby of the $19^{\text {th }}$ academic building of L'viv Polytechnic National University in 2015 after the completion of reconstruction and restoration works (photo by M. Bevz).

\section{Conclusion}

The interiors of the $19^{\text {th }}$ century academic building (formerly the Highest Regional Court of Galicia) require further research of other covered by paints, whitewashed paintings. The architectural molded decoration on the facades of the building and in the interiors of many rooms - in the meetings halls, lobby of the service entrance also requires restoration.

The next stage in the restoration and reproduction of the authentic decoration of the interior of the main lobby of the building should be, in our opinion, as follows:

- Reproduction of molded rosette in a square mirror on the ceiling, taking saved rosettes in the meeting room on the second floor as a reference; 
Completion of restoration works on the lions figures by Leonard Marconi;

- Changing the architectural solution of the interior of the lobby with arrangement of the place for the watchman;

- Restoration of the original coloration of the walls of the lobby (the research revealed a decorative coloring in several colors with a bright solution of painting the pilasters and 'mirrors' on the walls between the pilasters, framed by vertical and horizontal modeling;

- Construction and design work for elimination of the subsidence of the floor and foundations of the staircase march;

- Changes in the lighting system to an approximate to the historical one of the end of the XIX and early XX centuries.

\title{
Sources
}

[1] Architektura Lvova. Chas i styli XIII-XXI st., 2008. Nauk. red. Y.Birulov, Lviv: Tsentr Europy, 2008, s. 275.

[2] Archive of the department of Architecture and Conservation: 2012-2014. Project documentation and materials of research and restoration of the main lobby of the 19th academic building of NULP, ark. 1-12.

[3] Bevz M., Hetmanchuk S., 2015. Restavratsijne vidtvorennia chudozhnich rozpysiv kintsia XIX st. u vestybiuli 19 navchalnoho korpusu Natsionalnoho universytetu "Lvivska Politechnika", L'viv: vydavnytstvo L'vivskoji Politechniky, 2015, Naukowo-metodyczne vydannia. - 16 s. (in ukrainian).

[4] Bevz M., 2014. Pamiatky arkhitektury mista L'vova zbudovani iz zastosuvanniam romancementu. Nasha spadschyna. No1. - L'viv: 2014. - P. 47-51(in ukrainian).

[5] Bevz M., 2013. Problems of Protection and Conservation of Historical Monuments of L'viv built using Romancement. Budownictwo i architektura. Politechnika Lubelska. - Lublin, 2013. - Vol/ 12(4). - P. 177-188.

[6] Eder P., 2014.OsoblyvostistvorenniaVyschchohoKrajovohoSudu u Lvovi u skladiAvstriitaAvstro-Uhorshchyny (1855-1918). Chasopys Kyivskoho universytetu prava. - Kyiv: 2014. - No 3. - P. 34-40 (in ukrainian).

[7] Irina Kotłobułatowa. 2002. Lwów na dawnej pocztówce. L'viv na davniy grafitsi. Krakow, wydawnictwo Antykwa. 2002. C. 200-201.

[8] https://uk.wikipedia.org/wiki/Вý лиця_Кня́ зя_Рома́ на_Львів. 03.11 .2017 (in ukrainian).

[9] http://www.pohlyad.com/istoria/n/4766, 03.11.2017 (in ukrainian).

\section{Konserwacja i rekonstrukcja artystycznej malarskiej dekoracji sufitu z końca XIX wieku w budynku akademickim Politechniki Lwowskiej}

\begin{abstract}
Streszczenie: Artykuł przedstawia badania nad dekoracją artystyczną i praktyczne prace związane z konserwacja malowideł ściennych głównego holu dawnego budynku Sądu Krajowego Galicji. Budynek wykorzystywany dziś jako uczelniany korpus na potrzeby Politechniki Lwowskiej. Pierwsza część prac restauracyjnych została przeprowadzona w latach $2012-2014$. Metoda rekonstrukcyjnych prac polegała na oczyszczeniu sufitu od nawarstwień, konserwacji zachowanych fragmentów, odtworzeniu niezachowanych części.
\end{abstract}

Słowa kluczowe: budynek uczelni, dawny Sąd Krajowy Galicji, holl, malowidła ścienne, XIX wiek, konserwacja i rekonstrukcja, Lwów.

Translated by Anna Hadzalo 